\title{
Corporate Social Responsibility (CSR) Practice in Bahrain
}

\author{
Khaled Ibrahim Al-Tarawneh \\ University of Bahrain
}

\begin{abstract}
Purpose: The aim of this paper is to investigate the level of CSR disclosure by Bahraini listed companies in order to evaluate their participation towards the country economic development and to examine whether Bahrain is in line with the international community order in complying with global social and environmental sustainability standards. The study also analyzes sustainability variations among Bahraini companies relative to some firm characteristics such as firm's community- sensitivity, firm size and profitability.
\end{abstract}

Methodology: A disclosure index (scorecard) incorporating 27 items of CSR information was applied to a sample of 29 Bahraini listed firms in order to measure the level of CSR in Bahrain. Mean comparisons and regression analysis were used to explain variations in CSR among the sampled firms.

Findings: The findings indicate that the overall CSR in Bahrain is $41 \%$ of the utilized scorecard index. Further, the analysis indicates that firm sustainability differs according to the sub parts of sustainability. The average subindices were $42 \%$ for social disclosure, $52 \%$ for corporate governance disclosure and $26 \%$ for environmental disclosure. Only 7 companies out of the 29 in the sample have average index over 50\%. In general, this level of CSR is still below 50\% of the anticipated level of sustainability according to international sustainability standards. The results also revealed that large firms and community- sensitive firms have more CSR level than smaller and less community- sensitive firms. Regression analysis incorporating firm size, firm sensitivity and firm performance indicates that only firm performance represented by net income appears to be a significant explanatory variable in explaining CSR variations among firms.

Originality: the paper offers new insights in explaining CSR in general and specific insights into research in emergent economies such as that of the GCC area.

Keywords: Corporate social responsibility, Sustainable development, Corporate governance, community involvement, community sensitivity, and involuntary disclosure.

\subsection{Introduction:}

Recently, the Bahrain government has great emphasis on pursuing its sustainable economic development as indicated in its 2030 Economic Vision. Such sustainable development would possibly be achieved as long as organizations in the country maintain sustainable practices. Over the past two decades, the Bahraini government has encouraged the conduct of many meetings, seminars, forums and symposiums on this issue. As a matter of fact, Bahrain has recently hosted a UN forum on sustainable development in May 2015. The country has been selected to host this important international forum because of its continued international achievements in issues related to sustainable development. In 2010, Bahrain was selected as a winner for the UN award for the Millennium Development Goals (MDG). Accordingly, the Bahraini government exerts substantial efforts to increase public and organizational awareness towards the achievement of certain societal and environmental values that are essential parts of any successful sustainable economic development. For instance, research as indicated below has shown that increasing awareness and implementation of corporate social responsibility (CSR) that presumably would reflect favorable social and environmental values can bring good reputation for the organization, high morale among employees, more legitimacy from the community and may attract more investments.

As a response to these governmental efforts, many enterprises in Bahrain have started to recognize the need for more spiritual values such as social equity, social responsibility, community participation and environmental protection as essential public concerns to be addressed in order to maintain sustainable business practice. 
Due to this pressure from the government and some other stakeholders to be more transparent about business activities, many of the listed companies in Bahrain have voluntarily responded by disclosing information beyond the obligatory financial statements, and thus reporting information about their activities and their social and environmental impacts on society.

Consequently, there has been a progressive growth of sustainability reporting practice in Bahrain especially by business firms. This is clear through the increased number of companies issuing sustainability reports in recent years in order to show that their business practice is more humane, more ethical and more responsible towards the achievement of the government's sustainability mission.

The question that would arise which is the main purpose of this research paper is to investigate whether the reported sustainability performances by Bahraini companies match the expectations raised by the required sustainable economic development of the country. Therefore, this study aims to investigate whether the level of reported sustainable practice by Bahraini firms reaches an acceptable level based on international sustainability standards that would lead to classify such practice as sustainable. This is an urgent research question which has not been addressed by previous researchers. The results of such investigation would give indication whether Bahrain is in the right track for its sought sustainable development. That is, if the results show that higher level of sustainability performances are reported by Bahraini firms, then we would conclude that the government has succeeded in shaping the practice of business enterprises towards sustainability and this in turn will lead to the achievement of its sought sustainable development. On the other hand, if the results indicate low level of sustainability performances by Bahraini companies, then the government represented by its regulatory agencies would be advised to follow other mechanisms in order to induce sustainability practices of Bahraini companies.

\subsection{Objectives of the Study:}

1- To explore how the practice of CSR by Bahraini companies can strengthen and advance sustainable economic development for the country in the sense that such practice can lead to healthy and prosperous society.

2- To analyze sustainability variations among Bahraini companies relative to some firm characteristics such as industry type, size and profitability. This analysis may help in planning the economic development of the country.

3- To measure the level of reported sustainability by Bahraini companies in order to evaluate corporate participation towards the achievement of the country's sustainable economic development. In fact, CSR and economic development interdependence have far more economic and societal benefits than just doing acceptable practice. They have the potential to raise Bahrain's ranking on a number of global indices.

4- To provide evidence that Bahrain is in line with the international community order by complying with global social and environmental standards. This can be achieved by comparing the level of reported sustainability in Bahrain with an international CSR index that is recommended globally.

5- Based on the results, draw conclusion regarding the participation of companies towards the country economic development. This in turn will help in assessing the needs, opportunities and challenges for CSR capacity building in Bahrain.

\subsection{Corporate Sustainability and Economic Development}

Recently most corporations around the world have confronted with increased pressure from internal and external stakeholders to report not only on their financial performance, but also on their social and environmental performance. Ballou et al. (2006) cited that corporate sustainability is a conjunction of two terms-sustainable development and corporate social responsibility. Corporate social responsibility (CSR), also referred to as "Triple bottom line reporting' (TBL) requires reporting non-financial key performance indicators related to social and environmental issues in addition to the traditional financial performance indicators. Sustainable development is a broad concept that balances the need for economic growth with environmental protection and social equity. Corporate social responsibility is dedicated to a broader set of stakeholders, not just shareholders (Ballou et al. 2006). That is, corporate sustainability reports can reach local communities, environmental groups, legislators, employees, and investors.

Recently, the need for CSR reporting arose as a response to many corporate scandals, financial crises, climate change, the commitment to a lower-carbon future and concern about human rights, product safety, poverty reduction, etc. (Noronha, Tou, Cynthia, \& Guan, 2012). 
In other words, it became a necessary tool in order to seek sustainable development and should be more than just an effective public relations tool adopted by a company to increase corporate profitability (Tinker \& Niemark, 1987).

However, examining the reasons and methods of companies' corporate social responsibility (CSR) reporting appears a promising field of research, and sustainability reporting becomes the subject of increased attention from the business as well as the academic community.

Corporate sustainability should not be an isomorphic practice in which a firm pretends the concern towards social affairs while the real motive is to achieve higher profits. Rather, corporate sustainability should be linked to its responsibility towards social, environmental, and economic issues addressed in its daily activities. This means that the business firm could have sustainability embedded in all of its policies; human resource policies, health and safety measures, employees instructions, supply chain activities, engagement with the local community, social and educational activities, environmental concerns, sustainable consumption, financial and governance decisions, new product or service innovations, and so forth. Once the firm addresses the concerns of these issues in its policies and business strategies, then we have a sustainable business enterprise or a socially responsible firm. If all firms follow this type of sustainability at the micro level, then there would be sustainability at the macro level for the whole economy of the country. A sustainable enterprise economy produces wealth, preserves the natural environment and nurtures social capital (McIntosh, 2008, p. 147). If the enterprise, in all its shapes and forms, can adopt sustainability as its template according to the CSR standards, then we would have a sustainable economic unit. This sustainable unit along with others with similar practice will help in gearing production, consumption and efficiency to finding innovative and profitable solutions to issues of clean energy, the conservation of biological resources, increasing transparency and accountability of organizations, and decision-making and finding leaders for the common good (McIntosh, 2008, p. 140).

According to the UNCTAD 2011 World Investment Report, CSR standards can help governments on their economic developments. The report suggests the manifestation of CSR into national policies and international trade and investment regimes. In this regards, the report emphasized two critical issues to be addressed; improving CSR reporting by business firms highlights future policy for development and strengthening capacity building program which assists firms in developing countries to meet international best practice in this area.

As stated by Porter and Kramer (2006), when looked at strategically, CSR can become a source of tremendous social progress, as the business applies its considerable resources, expertise, and insights to activities that benefit society, then a symbiotic relationship develops: the success of the company and the success of the community become mutually reinforcing.

\section{Literature Review:}

Most prior studies of corporate social responsibility (CSR) disclosures are conducted on firms from developed countries (i.e. Bolivar and Garcia, 2004; Branco and Rodrigues, 2008; Bolivar, 2009; Razeed, 2010 and Pozniak et al., 2011). For these countries, corporate sustainability is not an important issue to their economic development simply because their economies are already well developed. For this reason the research questions of these studies were focused on various issues such as the market reaction to the level of voluntary disclosures (i.e. Ingram, 1978; Anderson and Frankle, 1980; Jaggi and Freedman, 1982; Freedman, 1986), studying the relationship between performance and CSR (i.e. Artiach et al., 2010; Nilipour and Nilipour, 2012; Tsoutsoura, 2004; McGuire et al., 1988), Or studying the factors or organizational characteristics that explain the extent or variations of corporate voluntary disclosure (i.e. Lindblom, 1984; Guthrie and Parker, 1989; Wallace et al., 1994; Wallace and Naser, 1995; Naser and Al-Khatib, 2000;

However, there is substantial evidence that societies around the world are demanding corporations to be more socially responsive (Ballou et al., 2006). As such, the choice to begin reporting on sustainability issues would appear to be in line with the social values people appreciate or favor. The organization perhaps most acknowledged as the leader in the development of sustainability reporting guidelines (Ballou et al., 2006; Gray, 2006; Woods, 2003), claims accrue benefits with respect to networking and communications, brand and reputation enhancement (www.globalreporting.org), to the extent that shareholders interpret such benefits as leading to increased long-term value for the firm and the initiation of sustainability reporting would be expected to lead to positive market reactions[5]. The practice of CSR at the organizational level is found to be linked to the configuration and transformation of societal development. As indicated by Porter and Kramer (2006): CSR can 
become a source of tremendous social progress, as the business applies its considerable resources, expertise, and insights to activities that benefit society. That is, the success of the company will reinforce the success of the society.

Kitzmueller and Shimshak (2012, p. 58) stated that "CSR constitute a special form of investment innovation that benefit society with some costs in the short run but would result in positive benefits in the long run. If a business implements its sustainability report accurately, completely, and timely, it will be able to increase its productivity and efficiency through process optimization. Therefore, cost savings are promised, which in turn, will result in higher economic return and increased firm's value. Hence, the reporting firm might enjoy the benefit of profit maximization or a better financial performance.

Conceptually, CSR refers to a company's voluntary contribution to sustainable development beyond what is required by law or regulation. Even though sustainability reporting is still voluntary, public and institutional pressure rises constantly. Thus, firms that report before it becomes mandatory may enhance their legitimacy and satisfy the expectations of internal and external stakeholders (Lindblom, 1984; Guthrie and Parker, 1989; Patten, 1992; Mathews, 1993). This in turn may create, maintain, or improve the business relationship with stakeholders and increase their understanding for the business activities and strategies. If sustainability activities are implemented accurately and contribute positively towards a sustainable economic development, the reporting firms are most likely to enjoy an improved image as well as a better reputation.

These conceptual benefits have attracted many large global companies to practice CSR. According to a recent survey by KPMG in 2011, 95\% of the 250 largest global companies currently report on CSR issues. Hence, the area of reporting practices of companies appears to be a promising field of research for academics around the world. As contended by some other researchers, business firms should create value to all of theirs' constituencies by seeking long term benefits to investors, community and environment (Donaldson and Preston, 1995; Mackey, 2005).

However, numerous theories have been used to explain the existence of corporate disclosure of financial and nonfinancial information (CSR). For example, because of the information asymmetry between the different stakeholders, as explained by Agency Theory (Jensen and Macklin, 1976), companies use the disclosure of different information related to a company's performance (financial information) in order to decrease these asymmetries (Cormier, Magnan, \& Van Velthoven, 2005). Other empirical research has used legitimacy and stakeholder theory to Justify CSR reporting as a mean of reducing information asymmetry (Deegan, 2002). Both theories provide an argument that CSR disclosure is a way of information asymmetry reduction and therefore can be an effective tool to legitimize the company's activities among the wide range of its stakeholders. Thus, these theories overcome the limitation of Agency theory, which is mostly focused on monetary considerations (Ferrero et al., 2013). According to legitimacy theory, companies are allowed to operate in their societies as entities as long as they adopt the practices that are in compliance with societal norms, expectations and values (Suchman, 1995 and Deegan, 2002). When it comes to CSR, it also implies that a company can gain legitimacy by voluntarily disclosing environmental and social information (Deegan, 2002).

Some other researchers adopted the stakeholder Theory to explain CSR by companies (Longo, Mura, \& Bonoli, 2005; Doukakis, Kapardis \& Katsioloudes, 2005; Uhlaner, van Goor-Balk, \& Masurel, 2004). Stakeholder theory was first introduced in 1984 by Freeman and the core of this theory holds that companies have a social responsibility, meaning that they are obligated to consider the interests of all stakeholders groups affected by their actions. Therefore, not only shareholders but also other stakeholders of the company such as suppliers, customers, employees, etc. should be considered relevant in the decision making process of the company. A company should seek to provide a balance between the interests of its diverse stakeholders and CSR reporting might be an effective tool to satisfy their information needs and minimize the information asymmetry. According to Freeman (1984) companies try to achieve higher transparency in order to gain the approval of its diverse stakeholders. CSR reporting is therefore used to engage with different stakeholders groups that are deemed essential for the viability of the company (Roberts, 1992; Ullmann, 1985). Additionally, stakeholder theory is considered to be easy to grasp by practitioners. For example, a recent study on the CRS reporting practice of European companies by Bonson and Bednarova (2014) has indicated that the Spanish Accounting and Business Association (AECA)'s Integrated Scorecard is consistent with this theory in a sense that it provides information to all stakeholders by grouping the key performance indicators into four subcategories: economic, social, governance and environmental. 
Some other studies found a link between industry where the company operates and its CSR reporting practices (Frynas, 2010; Azim, Ahmed, \& Islam, 2009; Outtes-Wanderley et al., 2008; Ogrizek, 2002 etc). For example, Azim et al. (2009) and Ogrizek (2002) concluded that financial services among all other industries represent the leading sector. The study of Frynas (2010) found that the Oil and gas companies scored the highest rank in terms of CSR reporting. Outtes-Wanderley et al. (2008) concluded that the energy sector, banking and telecommunications reported the most on sustainability. Hence, these studies present contradictory results given the fact that they have ignored other industry-specific factors such as the level of risk and societal and environmental sensitiveness. Whereas, Snider et al. (2003) stressed that companies operating in an industry with higher social and environmental impacts face stronger stakeholder demands for greater transparency. Facing this scrutiny, these companies are required to legitimize their actions more than companies operating in low risk sectors. As reporting plays an important role in the legitimacy process, CSR disclosure might be a very effective tool to manage the perception and reputation of the company (Cho, Roberts, \& Patten, 2010). A recent study by Young and Marais (2012) is a great contribution to the literature on CSR. The study conducts a content analysis to a number of research studies on CSR and provides an organized set of reasons to explain why companies report CSR. Table 1 below provides a summary to the set of reasons and the reference study or studies that indicated such reasons.

Table 1

\begin{tabular}{|l|l|}
\hline Reasons to report on CSR & Reference \\
\hline 1-To display its responsibility towards a wide range of stakeholders & Deegan and Samkin (2006) \\
\hline $\begin{array}{l}\text { 2- To respond to stakeholders' expectations and contribute to society } \\
\text { well-being }\end{array}$ & Morsing and Shultz (2006) \\
\hline 3- To manage and maintain their own legitimacy & $\begin{array}{l}\text { Archel, Husillos, Larrinaga, and Spence } \\
\text { (2009), Castelló and Lozano (2009), Makela } \\
\text { and Nasi (2010), Reverte (2009), Yongwanich } \\
\text { and Guthrie (2007), Deegan (2002) }\end{array}$ \\
\hline $\begin{array}{l}\text { 4- To guard a company's reputation and identity by engaging with } \\
\text { Stakeholders }\end{array}$ & Reynolds and Yuthas (2008) \\
\hline $\begin{array}{l}\text { 5-Long-term profitability by reducing information asymmetries and } \\
\text { improving stakeholder decision making }\end{array}$ & $\begin{array}{l}\text { Merkl-Davies and Brennan (2007), } \\
\text { Du, Bhattacharya, and Sen (2010) }\end{array}$ \\
\hline 6-To diverse institutional pressure & Young and Marais (2012) \\
\hline
\end{tabular}

However, regardless of the justifications or the reasons for CSR reporting, the extent and form of CSR reporting have become as an important issues to be considered when judging corporate accountability towards societies. This can be achieved by comparing the level of CSR by different companies. Therefore, over the last two decades, many global standards were proposed by different organizations around the globe. For example, Marimon et al (2012) provides a brief classification of corporate responsibility standards such as UN Global Compact Principles, GRI, OECD Guidelines for Multinational Enterprises, ISO 26000, AA1000, ISO 14001 and SA88000. Apparently, there is a need to have uniform international CSR reporting standards. However, among all of these standards, the Global Reporting Initiative (GRI) guidelines merit special attention as they are currently the most widely used (Ballou et al., 2006; Roca \& Searcy, 2012). GRI reports currently comprise forty percent of all corporate responsibility reports worldwide (Marimon et al., 2012).

GRI disclosure is based on triple bottom line including three sets of indicators (economic, environmental and social). Even though GRI reporting has spread around the world, there is still criticism relating to the large number of indicators proposed (84 indicators), and the fact that it is quite expensive for companies to prepare the report in accordance with GRI standards, which might be the reasons for the ongoing reluctance of some companies to adopt this framework. These global standards are currently utilized by many researchers to measure corporate responsibility reporting in different region of the world. A review to some studies that have been conducted on CSR in developing nations is provided below. Khasharmeh and Suwaidan (2010) evaluated the CSR in the traditional annual reports by manufacturing listed companies in GCC countries and examined the impact of company variables in exploring variation between the sampled companies in this type of disclosure. They investigated a total of 60 annual reports issued by listed companies in the GCC. The study concluded that, on average, sampled companies provided only $26 \%$ of 45 items included in the indices with only 8 companies receiving disclosure scores of $40 \%$ or more. Further, it was revealed that the UAE outscored other countries in 
CSR disclosure, and firm size and audit firms were found as major variables in explaining the variation on CSR disclosure between the GCC countries. In Malaysia, Zakaria and Dewa (2010) conducted a study about corporate social reporting in six Malaysian financial institutions. They used the content analysis method to identify and describe CSR patterns in websites and annual reports. The study found that most of banks under study disclosed information related to products and consumers, employees and community involvement. The results provided further evidence that CSR disclosures in Malaysia are ad-hoc, general and self laudatory. Also, the results provide some preliminary evidence of the possibility that CSR disclosures in Malaysia represent attempts by companies to improve their corporate image and to be seen as responsible corporate citizens.

Bonson and Bednarova (2014) conducted an empirical study to analyze the extent to which European companies report on CSR indicators, according to the Integrated Scorecard Taxonomy Scoreboard of the Spanish Accounting and Business Association (AECA), and the factors that can influence its use. Their content analysis was conducted on the annual sustainability reports on the websites of 306 Euro-zone companies listed in the STOXX Europe 600. The results revealed an intensive use of corporate governance indicators, a moderate disclosure of environmental key performance indicators (KPIs), and a low use of social indicators. The study also showed that there is an influence of sector, and the listing in DJSI on the extent of sustainability reporting. Tewari and Dave (2012) utilized the GRI standards to measure the level of CSR by a sample of Indian Companies and Multinational Companies operating in the Information and Technology sector in India. According to their findings, sustainability reports as a medium of CSR communication are quite ignored and only a few companies publish the sustainability report.

\section{Methodology}

This study is utilizing a content analysis in order to examine the level of CSR by Bahraini companies. Content analysis has been widely employed in CSR research (Gray et al, 1995; Parker, 2005; Thomson, 2007; Bonson and Bednarova, 2014; etc) and is the most common method of analyzing social and environmental reporting, particularly in firms (Milne and Adler 1999).

\subsection{Sample and Data:}

To examine the extent of CSR reporting by Bahraini companies, a sample of 29 listed companies were explored. Actually all 45 listed companies were considered initially but only 29 companies were found appropriate for the purpose of this study in terms of the availability of CSR information on their Websites or annual reports.

The study compiles data on selected CSR indicators that are globally recognized as proxies for corporate sustainability. This study is utilizing CSR indicators that are applicable to Bahrain as a country with an emergent economy. A modified version of the GRI (Integrated Scorecard) similar to that used by Bonson and Bednarova (2014) is used here to measure corporate sustainability in Bahrain. Table (2) summarizes the indicators of the suggested integrated scorecard applicable to Bahrain according to three subcategories: social; governance and environmental. The items in the table are selected from the GRI-G3 indicators that are applicable to companies in Bahrain.

Table (2) Indicators of Bahrain's Integrated Scorecard:

\begin{tabular}{|c|c|c|c|}
\hline Social Indicators (14) & $\begin{array}{l}\text { Human resources } \\
\text { Community involvement } \\
\text { Product and customer }\end{array}$ & $\begin{array}{l}\text { Employee training } \\
\text { Employee turnover } \\
\text { Gender diversity } \\
\text { Seniority } \\
\text { Workplace safety measures } \\
\text { Employees fringe benefits } \\
\text { Promotion and rewarding policies } \\
\text { Financial supports and donations } \\
\text { Engagement in social activities } \\
\text { Product quality rating } \\
\text { Product warranties } \\
\text { Product promotion programs } \\
\text { Customer service centers } \\
\text { Customer relation and support } \\
\end{array}$ & $\begin{array}{l}1 \\
2 \\
3 \\
4 \\
5 \\
6 \\
7 \\
8 \\
9 \\
10 \\
11 \\
12 \\
13 \\
14\end{array}$ \\
\hline Governance Indicators (7) & $\begin{array}{l}\text { Direction } \\
\text { Monitoring }\end{array}$ & $\begin{array}{l}\text { Board members (size) } \\
\text { Independence of members } \\
\text { Executive Committee } \\
\text { Audit Committee } \\
\text { Internal audit unit } \\
\text { External Auditor } \\
\text { Nominations committees }\end{array}$ & $\begin{array}{l}15 \\
16 \\
17 \\
18 \\
19 \\
20 \\
21\end{array}$ \\
\hline Environmental Indicators (6) & $\begin{array}{l}\text { Resource efficiency } \\
\text { Pollution } \\
\text { waste }\end{array}$ & $\begin{array}{l}\text { Energy consumption } \\
\text { Water consumption } \\
\text { Pollution reduction and filtering } \\
\text { Control over emissions } \\
\text { Waste reduction } \\
\text { Recycling }\end{array}$ & $\begin{array}{l}22 \\
23 \\
24 \\
25 \\
26 \\
27\end{array}$ \\
\hline
\end{tabular}


The indicators are measured for the sampled companies using data that reflect practiced sustainability by these firms over the period 2011-2015 gathered through annual reports and websites. A CSR index using the Integrated Scorecard is found for each company in the sample by grouping the key sustainability indicators into three subcategories: social, governance and environmental. In fact, the most prevalent CSR activities practiced by the majority of firms in the sample are: community engagement and support, employee wellness, education reform, job creation and innovation, environment conservation, energy and water preservation, recycling, health and safety measures, corporate governance, and gender equality and diversity. Such practiced activities are reflected by the indicators in the integrated scorecard according to their subcategories.

\subsection{Variables:}

The dependent variable:

The dependent variable in this study is the level of corporate sustainability reporting (SCR) by Bahraini companies. To measure this variable, an index reflecting the level of CSR for each company was constructed as indicated in the analysis below.

The Independent variables:

Previous studies have explained variation of CSR among firms based on factors such as firm size, firm performance and firm type of business or industry. In this study, the variation among companies will be investigated using explanatory variables such as size, performance and firm's community sensitivity instead of industry. The community sensitivity hypothesis below explains the justifications for using firm's community sensitivity instead of focusing on the type of business.

\subsection{Study Hypotheses:}

\section{The general CSR level hypothesis:}

Since the main concern of this study is to investigate whether the reported sustainability performances by Bahraini companies match the expectations raised by the required sustainable economic development of the country. Therefore, this study aims to investigate whether the level of reported sustainable practice by Bahraini firms reaches an acceptable level based on international sustainability standards that would lead to classify such practice as sustainable.

To investigate the extent of CSR in Bahrain in general, the first hypothesis can be set as:

HO1: Reported CSR by Bahraini companies does not comply with global CSR indicators.

\section{Community sensitivity hypothesis:}

Prior literature has shown evidence on the link between CSR practice and the industry where the company operates (Frynas, 2010; Azim, et al, 2009; Outtes-Wanderley et al., 2008; Ogrizek, 2002 etc). Therefore, in this study it merits investigating what industry or sector is more or less sustainable than others which may indicate more or less participation in the sustainable development of the country. In this study, however, the impact of industry will be treated differently. Building on the notion of Legitimacy theory, however, this study investigates practiced sustainability among companies according to their relative community sensitivity instead of industry type. This study proposes that firms from different industries operate in two types of environments; community based operations and non-community based operations. Firms in service sectors (i.e. banking, insurance, telecommunication, etc) are community based because the bulk of their operations is oriented towards local communities. These firms rely heavily on local community in the conduct of their operations. While firms in other sectors such as manufacturing, merchandising, or construction are less community based firms because the bulk of their operations are not necessarily oriented towards local community due to the possibility of exporting their operations.

According to legitimacy theory predictions, community based firms may engage themselves in community activities and support in order to build better customer relations and legitimize their operations and maintain good image. Accordingly, these companies are considered community- sensitive, given the fact that their operations are directed to their local communities. Without community engagement, social and environmental care, employee welfare, and so on, these firms may lose their legitimacy and, therefore, may suffer negative consequences or low earnings. Building customer relations through community involvement is a priority for these companies in order to gain sustainable earnings. 
On the other hand, less community based firms whose products or services could be externally consumed can be classified as less community- sensitive given the fact that their outputs are not depending thoroughly on local customers. Therefore, it is expected that their community involvement may be less than that of the first group. That is, these firms may gain their legitimacy by other means that are not necessarily local.

To simplify the investigation, the study is comparing together CSR practices of the sectors based on their community sensitivity classification. For example; banking, insurance, and telecommunication firms; are community sensitive, while product-based and construction firms are less community sensitive.

Accordingly, this second hypothesis can be set as:

HO2: There is no significant difference in the level of CSR disclosures among Bahraini firms relative to their community-sensitivity.

\section{Size hypothesis:}

Many prior studies have shown that size of the firm is an effective variable in determining its CSR level (Gallo et al, 2011; Windsor et al, 2011; Levy et al, 2010; and Moroney et al, 2009). It is assumed that larger companies are subject to greater pressure by stakeholder demands and that is why they tend to report more on their CSR practices in order to legitimize their activities (Burke et al, 1986). Accordingly, the third hypothesis of this study can be set as:

\section{HO3: The level of CSR of large Bahraini firms is not significantly different from that of smaller size firms.}

\section{Performance Hypothesis:}

Prior research has shown contradictory evidence regarding the profitability of the firm as a control variable affecting the level of Corporate CSR. Since 1970s, researchers have been empirically investigating the link between CSR and financial performance of the firm. Some researchers have found a positive link (i.e. Margolis et al., 2009; Waddock and Graves, 1997) while others have found a negative link (i.e. Artiach et al., 2010; Nilipour and Nilipour, 2012; Tsoutsoura, 2004; McGuire et al., 1988). Those researchers have ascribed the negative association between CSR and performance due to the costs involved in practicing as sustainable. That is, Investing in CSR involves additional costs such as improved employee conditions, adoption of environmentally friendly practices, charitable donations etc. Such sustainable practice will put firms at an economic disadvantage compared to less socially responsible firms. Still some other researchers such as Fauzi et al. (2007) found no evidence of any significant association between CSR and financial performance. In this study, it is worth investigating the nature of association between the level of CSR of a Bahraini company and its economic performance.

If the study finds a positive relationship between practiced CSR and company profitability, then it can be concluded that Bahraini society embrace sustainable practice of companies and thus gives them legitimacy over their conduct of operations which is reflected in good performance. Thus the forth hypothesis can be set as:

H4: There is no positive significant relationship between the level of CSR and company performance.

\section{Analysis and Results}

In order to explore CSR reporting practices of Bahraini companies, a Corporate Social Responsibility Index (CSRI) score is calculated using the integrated scorecard described above. The index is found for each company in the sample by grouping the key performance indicators into three subcategories: social, governance and environmental. The approach to scoring items is essentially dichotomous in that an item under the subcategories scores one if reported and zero if it is not (see Haniffa and Cooke, 2002; Haniffa and Hudib, 2007). Scoring items are also additive and equally weighted to avoid potential scoring bias and scaling problems (Cooke, 1989). Therefore, the CSR index for each company can be found using the following equation:

\footnotetext{
$\mathrm{N}$$$
\mathrm{CSRIj}=\sum_{\mathrm{i}-1} \mathrm{Xi} / \mathrm{N}
$$

Where:

CSRIj = corporate social reporting index score for company $\mathrm{j}$.

$\mathrm{N}$ = number of items in the index

$\mathrm{Xi} \quad=1$ if the item is disclosed

0 if the item is not disclosed
} 
To find the extent of CSR by Bahraini companies, the index of CSR for each company is found using the integrated scorecard described above and according to equation (1). Table (3) presents the calculated indices for the sampled firms.

Table (3): Average index per company:

\begin{tabular}{|c|c|c|c|c|c|c|c|c|c|}
\hline & Company Name & $\begin{array}{l}\text { Social } \\
\text { Total } \\
(14)\end{array}$ & $\%$ & $\begin{array}{l}\text { Gov. } \\
\text { Total } \\
(7)\end{array}$ & $\%$ & $\begin{array}{l}\text { Env. } \\
\text { Total } \\
(6)\end{array}$ & $\%$ & $\begin{array}{l}\text { Scorecard } \\
\text { Index } \\
(27)\end{array}$ & $\%$ \\
\hline 1 & Batelco & 12 & 86 & 4 & 57 & 3 & 50 & 19 & 70 \\
\hline 2 & Zain & 10 & 71 & 4 & 57 & 2 & 33 & 16 & 59 \\
\hline 3 & Bahrain Cinema & 6 & 43 & 4 & 57 & 2 & 33 & 12 & 44 \\
\hline 4 & Seef Properties & 6 & 43 & 3 & 43 & 1 & 17 & 10 & 37 \\
\hline 5 & NASS Corp. & 5 & 36 & 3 & 43 & 0 & 0 & 8 & 30 \\
\hline 6 & Bah. Comm. Facil. & 8 & 64 & 4 & 57 & 1 & 17 & 14 & 52 \\
\hline 7 & Bah. Duty Free & 6 & 43 & 3 & 43 & 2 & 33 & 11 & 41 \\
\hline 8 & ALBA & 12 & 86 & 6 & 86 & 4 & 67 & 22 & 81 \\
\hline 9 & GIPC & 8 & 64 & 4 & 57 & 4 & 67 & 16 & 59 \\
\hline 10 & Bah. Dev. Bank & 4 & 32 & 3 & 43 & 1 & 17 & 8 & 30 \\
\hline 11 & NBB & 11 & 79 & 5 & 71 & 2 & 33 & 18 & 67 \\
\hline 13 & KHCB & 4 & 32 & 3 & 43 & 1 & 17 & 8 & 30 \\
\hline 14 & GFH & 5 & 36 & 3 & 43 & 1 & 17 & 9 & 33 \\
\hline 12 & BBK & 12 & 86 & 5 & 71 & 2 & 33 & 19 & 70 \\
\hline 15 & Ahli. Unit. Bank & 9 & 64 & 4 & 57 & 3 & 50 & 16 & 59 \\
\hline 16 & UGB & 4 & 32 & 3 & 43 & 1 & 17 & 8 & 30 \\
\hline 17 & Investcorp. Bank & 3 & 21 & 3 & 43 & 0 & 0 & 6 & 22 \\
\hline 18 & GIB & 4 & 32 & 4 & 57 & 1 & 17 & 9 & 33 \\
\hline 19 & BMI & 4 & 32 & 4 & 57 & 2 & 33 & 10 & 37 \\
\hline 20 & Arab Bank Corp. & 4 & 32 & 4 & 57 & 1 & 17 & 9 & 33 \\
\hline 21 & BISB & 5 & 36 & 3 & 43 & 2 & 33 & 10 & 37 \\
\hline 22 & Ithmar Bank & 6 & 43 & 5 & 71 & 2 & 33 & 13 & 48 \\
\hline 23 & Alsalam Bank & 5 & 36 & 4 & 57 & 2 & 33 & 11 & 41 \\
\hline 24 & Albaraka & 4 & 32 & 4 & 57 & 1 & 17 & 9 & 33 \\
\hline 25 & Bah. Flour Mill & 3 & 21 & 3 & 43 & 1 & 17 & 7 & 26 \\
\hline 26 & Delmon Poultry & 4 & 32 & 3 & 43 & 2 & 33 & 9 & 33 \\
\hline 27 & Esterad Invest. & 2 & 16 & 3 & 43 & 0 & 0 & 5 & 18 \\
\hline 28 & Arig & 2 & 16 & 3 & 43 & 1 & 17 & 6 & 22 \\
\hline \multirow[t]{2}{*}{29} & Ahlia Insur. & 3 & 21 & 3 & 43 & 1 & 17 & 7 & 26 \\
\hline & Overall Average & 5.89 & $42 \%$ & 3.68 & $52 \%$ & 1.57 & $26 \%$ & 11.14 & $41 \%$ \\
\hline
\end{tabular}

The extent to which Bahraini companies report on CSR according to the Corporate Social Responsibility Index (CSRI) scores calculated using the integrated scorecard are shown in table 3 above. The overall average disclosure index for all companies in the sample was 11.14 out of the 27 indicators in the integrated scorecard or $41 \%$ of the scorecard's index.

The average sub-indexes were 5.89 out of 14 or $42 \%$ for social disclosure, 3.68 out of 7 or $52 \%$ for corporate governance disclosure and 1.57 out of 6 or $26 \%$ for environmental disclosure. Only 7 companies out of the 29 in the sample have average index over 50\%. These are: ALBA with $81 \%$, Batelco with $70 \%$, BBK with $70 \%$, Zain with 59\%, Ahli United Bank with 59\% and Bahrain Comm. Facilities with 52\%. The remaining 22 companies have average indices that are less than $50 \%$. In general, the results showed a moderate use of corporate governance indicators, less than moderate use of social indicators and a low use of environmental indicators.

Accordingly, the first hypothesis cannot be rejected since the overall average of CSR for all firms was only $41 \%$ of the integrated scorecard index. This level is still below $50 \%$ of the anticipated level of sustainability according to international sustainability standards.

For the purpose of investigating the level of CSR according to community- sensitivity, the sampled firms were classified into two categories; community- based and non-community based. To emphasize the notion of firmcommunity interdependence, the categorization for community sensitivity was generated by searching the webcites and annual reports and by personal contacts to the sampled firms to find out whether earnings are generated locally or from outside sources. A firm that generates more than $50 \%$ of its earnings from local markets is categorized as high community- sensitive. 
On the other hand, a firm that generates more than $50 \%$ of its earnings from outside markets is categorized as less community- sensitive. According to this procedure, table 4 below shows the classification of sampled firms according to their community sensitivity. As indicated in table 5 below, the average CSR for communitysensitive firms is 12.53 items with a standard deviation of 4.185 and the average CSR for the second group is 9.33 items with a standard deviation of 4.376 .

Table 4: Average index per company according to community sensitivity:

\begin{tabular}{|l|l|l|l|l|l|l|l|l|}
\hline & High-sensitive Firms & $\begin{array}{l}\text { Index } \\
(27)\end{array}$ & $\%$ & & & $\begin{array}{l}\text { Less-Sensitive } \\
\text { Firms }\end{array}$ & $\begin{array}{l}\text { Index } \\
(27)\end{array}$ & $\%$ \\
\hline 1 & Batelco & 19 & 70 & & 1 & Seef Properties & 10 & 37 \\
\hline 2 & Zain & 16 & 59 & & 2 & NASS Corp. & 8 & 30 \\
\hline 3 & Bahrain Cinema & 12 & 44 & & 3 & Bah. Duty Free & 11 & 41 \\
\hline 4 & Bah. Comm. Facil. & 14 & 52 & & 4 & ALBA & 22 & 81 \\
\hline 5 & GIPC & 16 & 59 & & 5 & KHCB & 8 & 30 \\
\hline 6 & Bah. Dev. Bank & 8 & 30 & & 6 & GFH & 9 & 33 \\
\hline 7 & NBB & 18 & 67 & & 7 & UGB & 8 & 30 \\
\hline 8 & BBK & 19 & 70 & & 8 & Investcorp. Bank & 6 & 22 \\
\hline 9 & Ahli. Unit. Bank & 16 & 59 & & 9 & GIB & 9 & 33 \\
\hline 10 & Arab Bank Corp. & 9 & 33 & & 10 & BMI & 10 & 37 \\
\hline 11 & BISB & 10 & 37 & & 11 & Esterad Invest. & 5 & 18 \\
\hline 12 & Ithmar Bank & 13 & 48 & & 12 & Arig & 6 & 22 \\
\hline 33 & Alsalam Bank & 11 & 41 & & & & & \\
\hline 14 & Albaraka & 9 & 33 & & & & & \\
\hline 15 & Bah. Flour Mill & 7 & 26 & & & & & \\
\hline 16 & Delmon Poultry & 9 & 33 & & & & & \\
\hline 17 & Ahlia Insurance & 7 & 26 & & & & & \\
\hline & Average & $\mathbf{1 2 . 5 3}$ & $\mathbf{4 4 . 3 5}$ & & & Average & $\mathbf{9 . 3 3}$ & $\mathbf{3 4 . 5}$ \\
\hline
\end{tabular}

The second hypothesis states that there is no significant difference between the two groups' averages. This hypothesis investigates whether the two categories of firms in table 4 are different in the level of their reported CSR. Using SPSS, a comparison of the two groups' means was conducted to examine the significance level of the difference between the two means. Table 6 shows that the calculated t-test for the difference is 1.988. This value is slightly above the tabulated value of 1.96 for a $5 \%$ significant level. Therefore, the second hypothesis can be rejected. That is, there is a significant difference between the two groups' means. This indicates that community sensitive firms have more CSR level than less community sensitive firms.

\begin{tabular}{|c|c|c|c|c|c|}
\hline \multicolumn{6}{|c|}{ Table 5: Descriptive Statistics (Community Sensitivity) } \\
\hline & \multicolumn{3}{|c|}{ Community Sensitivity } & Statistic & Std. Error \\
\hline \multirow{10}{*}{$\begin{array}{l}\text { CSR per Company out of } \\
27 \text { items in the Index }\end{array}$} & \multirow[t]{5}{*}{ Com. Sensitive } & \multicolumn{2}{|l|}{ Mean } & 12.53 & 1.015 \\
\hline & & \multirow{2}{*}{$\begin{array}{l}95 \% \text { Confidence } \\
\text { Interval for Mean }\end{array}$} & Lower Bound & 10.38 & \\
\hline & & & Upper Bound & 14.68 & \\
\hline & & \multicolumn{2}{|l|}{ Variance } & 17.515 & \\
\hline & & \multicolumn{2}{|l|}{ Std. Deviation } & 4.185 & \\
\hline & \multirow{5}{*}{$\begin{array}{ll}\text { Not } & \text { Com. } \\
\text { Sensitive } & \end{array}$} & \multicolumn{2}{|l|}{ Mean } & 9.33 & 1.263 \\
\hline & & \multirow{2}{*}{$\begin{array}{l}\text { 95\% Confidence } \\
\text { Interval for Mean }\end{array}$} & Lower Bound & 6.55 & \\
\hline & & & Upper Bound & 12.11 & \\
\hline & & \multicolumn{2}{|l|}{ Variance } & 19.152 & \\
\hline & & \multicolumn{2}{|l|}{ Std. Deviation } & 4.376 & \\
\hline
\end{tabular}




\begin{tabular}{|c|c|c|c|c|c|c|c|c|c|c|}
\hline \multicolumn{11}{|c|}{ Table 6: Independent Samples Test (Community sensitivity) } \\
\hline & & \multicolumn{2}{|c|}{$\begin{array}{l}\text { Levene's Test } \\
\text { for Equality of } \\
\text { Variances }\end{array}$} & \multicolumn{7}{|c|}{ t-test for Equality of Means } \\
\hline & & \multirow[t]{2}{*}{$\mathrm{F}$} & \multirow[t]{2}{*}{ Sig. } & \multirow[t]{2}{*}{$\mathrm{t}$} & \multirow[t]{2}{*}{$\mathrm{df}$} & \multirow[t]{2}{*}{$\begin{array}{l}\text { Sig. (2- } \\
\text { tailed) }\end{array}$} & \multirow[t]{2}{*}{$\begin{array}{l}\text { Mean } \\
\text { Diff. }\end{array}$} & \multirow[t]{2}{*}{$\begin{array}{l}\text { Std. } \\
\text { Error } \\
\text { Diff. }\end{array}$} & \multicolumn{2}{|c|}{$\begin{array}{l}95 \% \text { Confidence } \\
\text { Interval of the } \\
\text { Difference }\end{array}$} \\
\hline & & & & & & & & & Lower & Upper \\
\hline \multirow{2}{*}{$\begin{array}{l}\text { CSR per } \\
\text { Company out } \\
\text { of } 27 \text { items in } \\
\text { the Index }\end{array}$} & $\begin{array}{l}\text { Equal } \\
\text { variances } \\
\text { assumed }\end{array}$ & 1.036 & .318 & 1.988 & 27 & .057 & 3.196 & 1.608 & -.103 & 6.495 \\
\hline & $\begin{array}{l}\text { Equal } \\
\text { variances not } \\
\text { assumed }\end{array}$ & & & 1.972 & 23.153 & .061 & 3.196 & 1.621 & -.155 & 6.547 \\
\hline
\end{tabular}

For the purpose of investigating the level of CSR according to the size category of firms; small versus large, the sampled firms were classified into the two categories according to the size of total assets. A company with total assets of BD 500 millions and above is classified as large and a company with less than BD 500 Millions is considered small firm.

\begin{tabular}{|l|l|l|l|}
\hline \multicolumn{4}{|l|}{ Table 7: CSR per Company (Size Category) } \\
\hline Size Category & Mean & N & Std. Deviation \\
\hline Small Firm & 8.77 & 13 & 2.48 \\
\hline Large Firm & 13.19 & 16 & 4.82 \\
\hline Total & 11.21 & 29 & 4.48 \\
\hline
\end{tabular}

Accordingly, table 7 shows that 13 companies were found to be small with average CSR of 8.77 items with a standard deviation of 2.48 and 16 companies were large with average CSR of 13.19 items with a standard deviation of 4.82. Hypothesis 3 states that there is no significant difference between large firms and small firms in terms of their CSR levels. Using SPSS, table 8 shows a mean comparison to the two groups (large versus small) averages and reveals that the difference between the two groups is significant since the calculated t-test value is 2.99 with a $\mathrm{p}$ value of 0.006 and this t- value is above the tabulated t- value of 1.96 at the 5\% significance level. Therefore, the third hypothesis can be rejected which indicates that large firms have higher levels of CSR than small firms in Bahrain.

In order to investigate the explanatory power of firm performance in explaining variations in CSR among companies as stated in hypothesis four, a regression model is utilized with three independent variables; firm size, community sensitivity and firm performance.

$$
C S R=\beta 0+\beta 1 \text { FSIZE }+\beta 2 \text { FPERF }+\beta 3 \text { FSENSIT }+\varepsilon
$$

Firm size is measured using total assets. Firm performance is measured using net income and community sensitivity is measured as a dummy variable with zero if the firm is categorized as non- sensitive and one if the firm is categorized as sensitive to community. Table 9 below shows that only firm performance (net income) is a significant independent variable with a p- value of 0.004 and a t- value of 3.15. Therefore, hypothesis four can be rejected at the 5\% significant level which means that there is a positive significant relationship between firm performance and the level of CSR. However, the regression results do not support the findings of independent samples results above for the other two independent variables. 


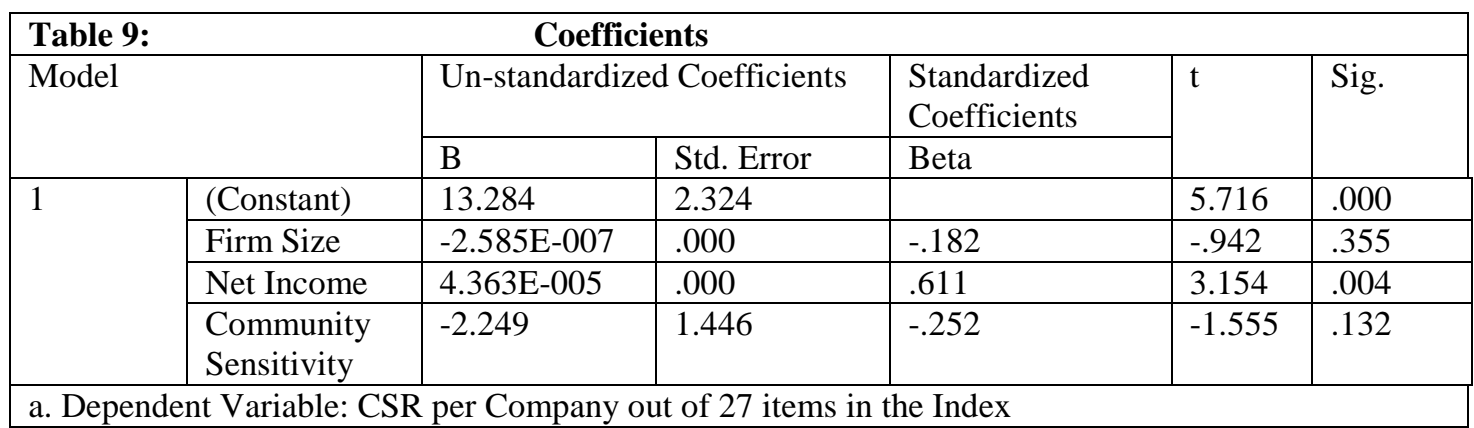

\begin{tabular}{|c|c|c|c|c|}
\hline \multicolumn{5}{|c|}{ Model Summary } \\
\hline Model & $\mathrm{R}$ & R Square & $\begin{array}{ll}\text { Adjusted } & \mathrm{R} \\
\text { Square } & \\
\end{array}$ & $\begin{array}{l}\text { Std. Error of } \\
\text { the Estimate }\end{array}$ \\
\hline 1 & $.627^{\mathrm{a}}$ & .393 & .320 & 3.696 \\
\hline
\end{tabular}

\section{Summary and Conclusion}

The objectives of this study are (1) to evaluate the level of CSR disclosure of listed Bahraini companies in order to evaluate the participation of companies towards the country economic development; (2)

To analyze sustainability variations among Bahraini companies relative to some firm characteristics such as firm's community- sensitivity, firm size and profitability; (3) to provide evidence that Bahrain is in line with the international community order by complying with global social and environmental standards. This can be achieved by comparing the level of reported sustainability in Bahrain with an international CSR index that is recommended globally. To achieve these objectives, a disclosure index incorporating 27 items of CSR information was applied to a sample of 29 Bahraini listed firms. The findings indicate that the overall CSR in Bahrain is $41 \%$ of the utilized scorecard index. Further, the analysis indicates that firm sustainability differs according to the sub parts of sustainability. The average sub-indices were $42 \%$ for social disclosure, $52 \%$ for corporate governance disclosure and $26 \%$ for environmental disclosure. Only 7 companies out of the 29 in the

\begin{tabular}{|c|c|c|c|c|c|c|c|c|c|c|}
\hline \multicolumn{11}{|c|}{ Table 8: Independent Samples Test (Size Category) } \\
\hline & & $\mathrm{F}$ & Sig. & $\mathrm{T}$ & $\mathrm{df}$ & $\begin{array}{l}\text { Sig. (2- } \\
\text { tailed) }\end{array}$ & $\begin{array}{l}\text { Mean } \\
\text { Difference }\end{array}$ & $\begin{array}{l}\text { Std. Error } \\
\text { Difference }\end{array}$ & Lower & Upper \\
\hline $\begin{array}{l}\text { CSR per } \\
\text { Company } \\
\text { out of } 27 \\
\text { items } \\
\text { in the Index }\end{array}$ & $\begin{array}{l}\text { Equal } \\
\text { variances } \\
\text { not } \\
\text { assumed }\end{array}$ & & & -3.18 & 23.32 & .004 & -4.418 & 1.389 & -7.289 & -1.548 \\
\hline
\end{tabular}

sample have average index over $50 \%$.

In general, this level of CSR is still below 50\% of the anticipated level of sustainability according to international sustainability standards. Furthermore, the sample was subdivided according to firm size in one part and according to its community sensitivity in another part to investigate whether companies vary in their CSR accordingly. The results revealed that large firms and community- sensitive firms have more CSR level than smaller and less community sensitive firms. A multiple regression model incorporating firm size, firm sensitivity and firm 
performance was utilized to explain variations of CSR among the sampled companies. Only firm performance represented by net income appears to be a significant explanatory variable in explaining such variations.

The current study has a number of limitations. First, the scope of this study is only limited to only 29 Bahraini listed companies that have disclosed CSR information. Second, the findings of this study may not be generalized to different countries with different business environments and cultures. Third, while an un-weighted disclosure index was used in this study, the findings might be different if a weighted disclosure index, which assesses the importance of each item in accordance with specific user group' perspective, were used. However, variables other than those included in the study may affect the extent of CSR. Further studies in the future may be needed to incorporate the impact of other potential explanatory variables on CSR but with a larger sample from all GCC countries.

\section{References}

Anderson, J. C., and Frankle, A. W. (1980), "Voluntary social reporting: An ISO-beta portfolio Analysis". The Accounting Review, Vol. 55, pp. 467-479.

Archel, P., Husillos, J., Larrinaga, C., and Spence, C. (2009), "Social disclosure, legitimacy theory and the role of the state". Accounting, Auditing \& Accountability Journal, Vol. 22 No. 8, pp. 1284-1307.

Artiach, T., Lee, D., Nelson, D. and Walker, J. (2010), "The Determinants of Corporate Sustainability Performance", Accounting and Finance, Vol. 50 No. 1, pp. 31-51.

Azim, M. I., Ahmed, S., and Islam, M. (2009), "Corporate social reporting practice: Evidence from listed companies in Bangladesh". Journal of Asia-Pacific Business, Vol. 10 No. 2, pp. 130-145.

Ballou, B., Heitger, D.L. and Landes, C.E. (2006), "The future of corporate sustainability reporting", Journal of Accountancy, Vol. 200 No. 6, pp. 65-74.

Bolivar, M. (2009), "Evaluation corporate environmental reporting in the Internet", Business and Society, Vol. 48 No. 2, pp. 179-205.

Bolivar, M. and Garcia, B. (2004), "The corporate environmental disclosures on the Internet:

The case of IBEX 35 Spanish", International Journal of Accounting, Auditing and Performance Evaluation, Vol. 1 No. 2, pp. 215-266.

Bonson, E. and Bendnarova, M. (2015), "CSR reporting practices of Eurozone companies", Spanish Accounting Review, Vol. 18 No. 2, pp. 182-193.

Branco, M. and Rodrigues, L. (2008), "Social responsibility disclosure: A study of proxies for the public visibility of Portuguese banks", British Accounting Review, Vol. 40 No. 2, pp. 161-181.

Burke, L., Logsdon, J. M., Mitchell, W., Reiner, M., and Vogel, D. (1986), "Corporate community involvement in the San Francisco Bay area". California Management Review, Vol. 28, pp.122-141.

Castelló, I., and Lozano, J. (2009), "From risk management to citizenship corporate social responsibility: Analysis of strategic drivers of change", Corporate Governance, No. 9, pp.373-385.

Cho, C., Roberts, R. and Patten, D. (2010), "The language of US corporate environmental disclosure", Accounting, Organizations and Society, Vol. 35, No. 4, pp. 431-443.

Cooke, T. (1989), "Voluntary corporate disclosure by Swedish companies", Journal of International Financial Management and Accounting, Vol. 1, No. 2, pp. 171-195.

Cormier, D., and Magnan, M, (2007), "The revisited contribution of environmental reporting to investors' valuation of a firm's earnings: An international perspective", Ecological Economics, Vol. 32 No. 3, pp. 613-626.

Deegan, C. (2002), "The legitimising effect of social and environmental disclosures - a theoretical foundation", Accounting, Auditing \& Accountability Journal, Vol. 15 No. 3, pp. 282-311.

Deegan, C. and Gordon, B. (1996), "A study of the environmental disclosure practices of Australian corporations", Accounting \& Business Research, Vol. 26 No. 3, pp. 187-99.

Deegan C and Rankin M (1996), "Do Australian Companies Report Environmental News Objectively? An Analysis of Environmental Disclosures by Firms Prosecuted Successfully by the Environmental Protection Authority", Accounting, Auditing and AccountabilityJournal, Vol. 9 No. 2, pp. 50-67.

Deegan, C., and Samkin, G. (2006), New Zealand Financial Accounting. Sydney: McGraw Hill.

Donaldson, T. and Preston, L. (1995), "The stakeholder theory of the corporation: concepts, evidence, and implications", Academy of Management Review, Vol. 20 No. 1, pp. 65-91. 
Du, S., Bhattacharya, C., and Sen, S. (2010), "Maximizing business returns to corporate social responsibilities: The role of CSR communication", International Journal of Management Reviews, Vol. 12 No. 1, pp. 819.

Fauzi, H., Mahoney, L. S. and Rahman, A. A. (2007), "The Link between Corporate Social Performance and Financial Performance: Evidence from Indonesian Companies", Issues in Social and Environmental Accounting, Vol.1 No.1, pp. 149-159.

Ferrero, J. M., Garcia-Sanchez, I. M., and Cuadrado-Ballesteros, B. (2013), "Effect of financial reporting quality on sustainability information disclosure". Corporate Social Responsibility and Environmental Management, http://dx.doi.org/10.1002/csr.1330.

Freeman, E. (1984), Strategic management: A stakeholder approach. Boston: Pitman Publishing.

Freedman, M. and Jaggi, B. (1986), "An analysis of the impact of corporate pollution disclosures included in annual financial statements on investment decisions", Advances in Public Interest Accounting, Vol. 1, pp. 193-212.

Frynas, J. G. (2010), "Corporate social responsibility and societal governance: Lessons from transparency in the oil and gas sector". Journal of Business Ethics, No. 93, pp 163-179.

Gallo, P.,and Christensen, L. (2011), "Firm size matters: An empirical investigation of organizational size and ownership on sustainability-related behaviors". Business and Society,No. 50, pp. 315-349.

Gray, R.H. (2006), "Social, environmental and sustainability reporting and organisational value creation? Whose value? Whose creation?", Accounting, Auditing and Accountability Journal, Vol. 19 No. 6, pp. 793-819.

Gray, R., Kouhy, R. and Lavers, S. (1995a), "Corporate social and environmental reporting:a review of the literature and a longitudinal study of UK disclosure", Accounting, Auditing \& Accountability Journal, Vol. 8 No. 2, pp. 47-77.

Guthrie, J. and Parker, L.D. (1989), “Corporate social reporting: a rebuttal of legitimacy theory”, Accounting \& Business Research, Vol. 19 No. 76, pp. 343-52.

Haniffa, R. and Cooke, T. (2002), "Culture, corporate governance and disclosure in Malaysian corporations", Abacus, Vol. 38 No. 3, pp. 317-349.

Haniffa, R. and Hudaib, M. (2007), "Exploring the Ethical Identity of Islamic Banks via Communication in Annual Reports". Journal of Business Ethics, Vol. 76 No. 1.

Ingram, R. W. (1980), "An investigation of the information content of certain social responsibilityDisclosure". Journal of Accounting Research, Vol. 18, pp. 14-22.

Jaggi, B. and Freedman, M. (1982), "An analysis of the information content of pollution disclosures", The Financial Review, September, pp. 142-52.

Jensen, M.C. and Meckling, W.H. (1976), "Theory of the firm: managerial behavior, agency costs and ownership structure", Journal of Financial Economics, Vol. 3, October, pp. 305-60.

Khasharmeh, H. and Suwaidan, M. (2010), "Social responsibility disclosure in corporate annual reports: Evidence from the Gulf Cooperation countries", International Journal of Accounting, Auditing and Performance Evaluation, Vol. 6 No. 4, pp. 327-345.

Kitzmueller, M. \& Shimshack, J. (2012), "Economic Perspectives on Corporate Social esponsibility", Journal of Economic Literature, Vol. 50, No. 1, pp. 51-84.

KPMG (2005). "International survey of corporate responsibility reporting". Available at: http://www.kpmg.com.au/Portals/0/KPMG\%20Survey\%20200500_3.pdf.

Longo, M., Mura, M., and Bonoli, A. (2005), "Corporate social responsibility and corporate performance: The case of Italian SMEs", Corporate Governance, Vol. 5 No. 4, pp. $28-42$.

Levy, D. L., Szejnwald, B. H., and de Jong, M. (2010), "The contested politics of corporate Governance, the case of the global reporting initiative". Business and Society, Vol. 49 No. 1, pp. 88-115.

Lindblom, C. E. (1984), "The accountability of private enterprise: Private - No. Enterprise - Y Yes. In: A. M. Tinker (Ed.)", Social accounting for corporations. New York: Marcus Weiner.

Mackey, J. (2005), “'Putting customers ahead of investors, in rethinking the social responsibility

of business: a reason debate featuring Milton Friedman, whole foods' John Mackey and cypress semi conductor's T.J. Rogers", Reason, Vol. 37 No. 5, pp. 28-37.

Mäkelä, H., and Näsi, S. (2010), "Social responsibilities of MNCs in downsizing operations: A Finnish forest sector case anlysis from the stakeholder, social contract and legitimacy

theory point of view”. Accounting, Auditing \& Accountability Journal, Vol. 23, No. 2,pp. 149-174. 
Margolis, J. D., Elfenbein, H.A. and Walsh, J. P. (2009), "Does It Pay To Be Good... And Does It Matter? A Meta-analysis of the Relationship between Corporate Social and Financial performance", http://papers.ssrn.com/sol3/papers.cfm?abstract_id=1866371 (16.05.2013).

Marimon, F., Alonso-Almeida, M., and Rodríguez, M. (2012), "The worldwide diffusion of the global reporting initiative: What is the point?", Journal of Cleaner Production, Vol. 33, pp. 132-144.

Mathews, M. R. (1993), "Socially responsible accounting". London: Chapman Hall.

McIntosh, M. (2008), "Sustainable enterprise and sustainable futures", in Suder, G.G.S. (Ed.),International Business Under Adversity: A Role in Corporate Responsibility, Conflict Prevention and Peace, Edward Elgar, Cheltenham, pp. 139-49.

McGuire, J. B., Sundgren, A. and Schneeweis, T. (1988), "Corporate Social Responsibility and Firm Financial Performance", Academy of Management Journal, Vol.31 No. 4, pp. 854-872.

Merkl-Davies, D., and Brennan, N. (2007), "Discretionary disclosure strategies in corporate narratives: Incremental information or impression management?" Journal of Accounting Literature, Vol. 26, pp. 116-196.

Milne, M.J. and Adler, R.W. (1999), "Exploring the reliability of social and environmental disclosures content analysis", Accounting, Auditing \& Accountability Journal, Vol. 12 No. 2, pp. 237-56.

Moroney, R., Windsor, C., and Aw, Y. T. (2011), "Evidence of assurance enhancing the quality of voluntary environmental disclosures: An empirical analysis". Accounting and Finance, http://dx.doi.org/10.1111/j.1467-629X.2011.00413.x

Morsing, M., and Schultz, M. (2006), "Corporate Social Responsibility Communication: Stakeholder information, response and involvement strategies', Business Ethics: A European Review, Vol. 15 No. 4, pp. 323-338.

Naser, K., and Al-Khatib, K. (2000), "Determinants of the depth of voluntary disclosure in the board of directors' statement in a sample of Jordanian listed companies". Advances in International Accounting, Vol. 13, pp. 99-118.

Nilipour, A. and Nilipour, A. (2012), "Survey of the Association between Financial Performance and Corporate Sustainability Performance (Case Study: Cement Companies Accepted at Tehran Stock Exchange)", Interdisciplinary Journal of Contemporary Research in Business, Vol. 3 No. 9, pp. 1084-1092.

Noronha, C., Tou, S., Cynthia, M. I., and Guan, J. J. (2012), "Corporate social responsibility reporting in China: An overview and comparison with major trends", Corporate Social Responsibility and Environmental Management, http://dx.doi.org/10.1002/csr.1276

Ogrizek, M. (2004), "The effect of corporate social responsibility on the branding of financial services", Journal of Financial Services Marketing, Vol. 6, No. 3, pp. 215-228.

Outtes-Wanderley, L., Soares, L., Lucian, R., Farache, F., and de Sousa Filho Milton, J. (2008), "CSR information disclosure on the web: A context-based approach analyzing the influence of country of origin and industry sector". Journal of Business Ethics, Vol. 82, pp. 369-378.

Parker, L. (2005), "Social and environmental accountability research: a view from the commentary box", Accounting, Auditing \& Accountability Journal, Vol. 18 No. 6, pp. 842-60.

Patten, D.M. (1992), "Intra-industry environmental disclosures in response to the Alaskan oil spill: a note on legitimacy theory", Accounting, Organizations and Society, Vol. 17 No. 5, pp. 471-5.

Porter, M. and Kramer, M. (2006), "Strategy\& society: the link between competitive advantage and corporate social responsibility", Harvard Business Review, December, pp. 78-93.

Pozniak L., Ferauge P., Armone, L. and Geerts, A. (2011), "Determinants of Internet corporate social responsibility communication", Global Journal of Business Research, Vol. 5, No. 4, pp. 1-14.

Razeed, A. (2010), "Determinants of environmental disclosure practices of US resource companies: Hard copy versus Internet reporting”. Available at: http:/apira2010.econ.usyd.edu.au/conference e_proceedings /APIR A-2010-295-Razeed-

Reverte, C. (2009), Do better governed firms enjoy a lower cost of equity capital?: $\quad$ Evidence from Spanish firms. Corporate Governance, 9(2), 133-145.

Reynolds, M., and Yuthas, K. (2008), "Moral discourse and corporate social responsibility Reporting", Journal of Business Ethics, Vol. 78, No. 1-2, pp. 47-64.

Roberts, R. (1992), "Determinants of corporate social responsibility disclosure: an application of Stakeholders theory", Accounting, Organizations and Society, Vol. 17 No. 6, pp. 595-612. 
Roca, L. C., and Searcy, C. (2012), "An analysis of indicators disclosed in corporate sustainability reports", Journal of Cleaner Production, No. 20, pp. 103-118.

Snider, J., Hill, R. P., and Martin, D. (2003), "Corporate social responsibility in the 21 stcentury: A view from the world's most successful firms", Journal of Business Ethics,Vol. 48, pp. 175-187.

Suchman, M. C. (1995), "Managing legitimacy: Strategic and institutional approaches", Academy of Management Review, Vol. 20 No. 3, pp. 571-606.

Tewari, R., and Dave, D. (2012), "Corporate social responsibility: Communication through sustainability reports by Indian and multinational companies". Global Business Review, Vol. 13, No. 3, pp. 393-405.

Thomson, I. (2007). "Mapping the terrain of sustainability accounting. In J. Unerman, J. Bebbington, and B. O’Dwyer (Eds.), Sustainability accounting and accountability", pp.19-37.

Tinker, T., and Niemark, M. (1987), "The role of annual reports in gender and class contradictions at general motors", Accounting, Organizations and Society, Vol. 12, No. 1, pp. 71-88.

Tsoutsoura, M. (2004), "Corporate Social Responsibility and Financial Performance”,http://responsiblebusiness. haas.berkeley.edu/documents/Final Paper on CSR_PDFII.pdf (11.04.2013).

Uhlaner, L., van Goor-Balk, A., and Masurel, E. (2004), "Family business and corporate social responsibility in a sample of Dutch firms", Journal of Small Business and Enterprise Development, Vol. 11 No. 2, pp. 186194.

Ullmann, A. (1985), "Data in search of a theory: A critical examination of the relationship among social performance, social disclosure and economic performance", Academy of Management Review, Vol. 10, pp. 450-477.

UNCTAD, United Nations Conference on Trade and Development (2008), "Guidance on Corporate Responsibility Indicators in annual reports". New York \& Geneva, United Nations Publication.

Waddock, S. and Graves, S. (1997). "The corporate social performance-financial performance link", Strategic Management Journal, Vol. 18 No. 4, pp. 303-319.

Wallace, R. S. O., Naser, K., and Mora, A. (1994), "The relationship between the comprehensiveness of annual corporate reports and firm characteristics in Spain", Accounting and Business research, Vol. 25, pp. 4153.

Wallace, R. S. O., and Naser, K. (1995), "Firm-specific determinants of the comprehensiveness

of mandatory disclosure in the annual corporate reports of firms listed on the Stock Exchange of Hong Kong", Journal of Accounting and Public Policy, Vol. 14, pp. 311-368.

Woods, M. (2003), "The Global Reporting Initiative", The CPA Journal, Vol. 73 No. 6, pp. 60-5.

Young, S., and Marais, M. (2012), "A multi-level perspective of CSR reporting: The implications of national institutions and industry risk characteristics", Corporate Governance: An International Review, Vol. 20 No. 5, pp. 432-450.

Yongvanich, K., and Guthrie, J. (2007), "Legitimation strategies in Australian mining extended performance reporting", Journal of Human Resource Costing and Accounting, Vol. 11 No. 3, pp. 156-177.

Zakaria S. and Dewa, N. (2010), "Corporate social responsibility (CSR) reporting in six Malaysian financial institutions, 2010 Oxford Business and Economics Conference Program, June 28 - 29, Oxford University, Oxford, UK. 